\title{
Narrative Stylistics: A Study of the Narrative and Discourse Strategies in Omotoso's Just Before Dawn
}

\author{
Bassey Ufot ${ }^{1}$ \\ ${ }^{1}$ Department of English, University of Uyo, Uyo, Nigeria \\ Correspondence: Bassey Ufot, Department of English, University of Uyo, Uyo, Nigeria. E-mail: \\ Garveyufot@yahoo.com \\ Received: March 4, 2014 \\ Accepted: March 24, 2014 \\ Online Published: March 27, 2014 \\ doi:10.5430/elr.v3n1p28 \\ URL: http://dx.doi.org/10.5430/elr.v3n1p28
}

\begin{abstract}
This paper is a stylistic study of the elements of narrative discourse in Kole Omotoso's Just Before Dawn (JBD) including its narrative plot, narrative discourse and chapter titles. After its initial restrained favourable reception in literary circles at its publication in 1988, Omotoso's $J B D$ has been largely neglected, receiving very little scholarly attention of especially stylistic kind thereafter. This study therefore focuses on the stylistic and semantic implications of the major features of the writer's narrative strategy in the book such as flashback, time shift, foreshadowing (prevision), elaboration and chapter titles. The study incorporates the theoretical postulations of Paul Simpson on narrative stylistics and discourse, and exemplifies the degree to which Omotoso's stylistic flourish in $J B D$ gives the story an imprint of individuality. The paper reveals the ways in which the author manipulates narrative sequence and the various stylistic elements of narrative discourse and deploys them symbolically. It concludes that based on these devices, the book assumes an archetypal, dialectical, paradoxical and symbolic character.
\end{abstract}

Keywords: Narrative, Discourse, Plot, Stylistics, Flashback, Time shift

\section{Introduction}

\subsection{Stylistics and Literary Discourse}

Stylistics as the linguistic study of literary and non literary style seeks to amalgamate linguistic and literary approaches to criticism by extending the linguist's 'literary intuitions' and the literary critic's 'linguistic observations' in order to make their relationship explicit and produce an adequate and relevant criticism of literature. It is an area of mediation between language and literature. Stylistics investigates all aspects of grammar and meaning especially in formal contexts, and it is as much a linguistic analysis of literary texts as it is a literary evaluation of language. Widdowson (1975) observes that the value of stylistic analysis is that it can 'provide the means whereby the learner can relate a piece of literary writing with his own experience of language and so extend that experience'(p.3). Stylistics is not just grammar or syntax which is limited to the level of the individual sentence. Whereas syntax is concerned with only the composition of several words into one sentence, stylistics incorporates this and regards further the composition of many sentences into a piece of discourse.

Stylistics, even though applicable to all kinds of texts whether literary or non literary, appears to be more frequently associated with literary texts. Matthews (2007) posits that it is 'the study of style in language: traditionally, of variations in usage among literary and other texts; now more generally, of any systematic variation, in either writing or speech, which relates to the type of discourse or its context' (p.386). Literature, it has been pointed out by Chapman (1973), is the most difficult type of language to approach stylistically because of the diversity and complexity which often appear in the course of investigation. Leech and Short (2007,p.11) assert that 'literary stylistics has implicitly or explicitly the goal of explaining the relation between language and artistic function.' For Mikov (2003), 'literary style is the style of literary works implemented in all components of a literary work i.e. on the level of language, ideas, plot, etc' (p.16). It is also the case that literary stylistics appears much more amenable to the criticism of literature, and this is the concern of this paper.

Literary stylisticians deploy the methods of stylistics to the language of literature and deal with the relationship between language and character, between author and audience, and between linguistic features and content value resulting in organized evaluation of literary discourse. According to Carter and Simpson, literary stylistics provides: 
the basis for fuller understanding, appreciation and interpretation of avowedly literary and author-centred texts. The general impulse will be to draw eclectically on linguistic insights and to use them in the service of what is generally claimed to be fuller interpretation of language effects than is possible without the benefit of linguistics (Carter and Simpson in Mills, 1995, p.4).

But a great deal of work in stylistics - including Olateju (2004), Ufot (2006), Coupland (2007) and Leech (2008) now treats literature as discourse; that is, as a group of sentences which carry meaning and which are contextual. Simpson (2004, p.8) points out that:

contemporary stylistics ultimately looks towards language as discourse: that is, towards a text's status as discourse, a writer's deployment of discourse strategies and towards the way a text 'means' as a function of language in context....- the way a text is constructed in language will, after all, have a crucial bearing on the way it functions as discourse.

If the textuality of the work has a bearing on the way it functions as discourse, the individuality of the writer as manifested in his lexical, grammatical and narrative choices in the work has a bearing on the textuality of the work as well as its overall function as discourse, for, as Matthews (2007) suggests, the literary study of stylistics focuses essentially on the 'relevant differences, other than in the dialect or language used, among individual writers, periods, or genres' (p.386). Discourse stylistics leads to 'a concentration of attention on discoursal techniques, and on the cultural, social or political resonances' of a narrative (Leech, 2008,p.180). Ultimately, this creates a three-way socio-linguistic code which thrives on the relationship of immediacy among language, literature and discourse such that the parts of a text are treated as interconnected and symbolic pieces of discourse often referred to as the text's narrative but frequently neglected in many stylistic investigations.

\section{Narrative Stylistics}

Narrative stylistics derives from the concept of narratology and narrative grammar. It involves the formal analysis of narrative texts from a tradition which is similar to European structural linguistics (Matthew, 2007). Narratology itself is the theoretical study of narratives paying particular attention to its levels and structures. Narratology focuses on the manifestations of narratives in language and the different media. It also focuses on the narrators - the person who narrates the story whether factual or fictional - and classifies them into autodiegetic narrators and heterodiegetic narrators. The former refers to the first person narrators, who are typically the heroes or heroines of the stories, while the latter is characteristically the omniscient narrator, the implied author. The omniscient narrator is detached from the events, and as Wales (2011) opines, 'may not even establish a discourse "relationship" with the implied reader' (p.286). Dramatic irony in the novel, as she argues, for instance, is often the result of the double perspective of the reader and the narrator.

Narrative discourse is the process of formal recollection and description of a series of activities for the purposes of ideology. For Simpson (2004), it 'provides a way of recapitulating felt experience by matching up patterns of language to a connected series of events'. According to him:

In its most minimal form, a narrative comprises two clauses which are temporally ordered, such that a change in their order will result in a change in the way we interpret the assumed chronology of the narrative events (p.18).

Simpson proceeds to illustrate this with the sentence:

John dropped the plates and Janet laughed suddenly.

and suggests that the temporal progression between the two actions described in the sentence would invite a completely different meaning were there to be any attempt to reverse the clauses to:

Janet laughed suddenly and John dropped the plates.

More fundamentally, however, this indicates that narratives require development, elaboration and embellishment. They also need sufficient degrees of stylistic flourish to bestow on them the imprint of individuality or personality, for, as Simpson argues, stories narrated without that flourish will often 'feel flat and dull' (p.19).

Although the task of providing an acceptable and rigorous model of narrative discourse has proved somewhat challenging for discourse stylisticians, there has been little disagreement on the procedure for isolating the various components of, say, a novel or a short story as well as the interconnectivity between these components. Simpson, for 
instance, makes a primary distinction between two basic components of narrative - narrative plot and narrative discourse as follows:

The term plot is generally understood to refer to the abstract storyline of a narrative; that is, to the sequence of elemental, chronologically ordered events which create the 'inner core' of a narrative. Narrative discourse, by contrast, encompasses the manner or means by which that plot is narrated. Narrative discourse, for example, is often characterized by the use of stylistic devices such as flashback, prevision and repetition - all of which serve to disrupt the basic chronology of the narrative's plot. Thus, narrative discourse represents the realised text, the palpable piece of language which is produced by a story-teller in a given interactive context (Simpson, 2004, p.20).

These elements of narrative discourse, as well as time shift and symbolic chapter titles, are deployed, as we shall see, by Omotoso in $J B D$.

\section{Elements of Narrative Discourse}

There are six basic stylistic units of analysis in narrative description. As identified by Simpson, these include:

a) Textual medium: This refers to the physical channel of communication by which the story is narrated. Common examples of textual media are the novel, film, drama, music or cartoon strip.

b) Sociolinguistic code: This expresses through language the historical, cultural and linguistic setting which underlies a narrative, locating the narrative in time and place by drawing upon the linguistic forms which reflect this socio-cultural context. Sociolinguistic code encompasses the varieties of accent and dialect used in a narrative by the narrator or the characters within the narrative including also the social and institutional registers of discourse deployed in the story.

c) Characterization 1: actions and events - This unit basically describes the way in which the development of character precipitates and intersects with the actions and events of a story. It accounts for the ways in which the narrative intermeshes with certain kinds of semantic processes such as those of 'doing', 'thinking' and 'saying', and shows how these processes are attributed to characters and narrators.

d) Characterization 2: points of view - This kind of characterization explores the relationship between mode of narration and a character's or narrator's 'point of view'. Mode of narration specifies whether the narrative is relayed in the first person, the third person or even the second person, while point of view stipulates whether the events are viewed from the perspective of a particular character or from that of an omniscient narrator, or indeed from some mixture of the two. The way speech and thought processes are represented in narrative is also an important determinant of point of view, although stylistically, this technique has a double function referring to both actions and events.

e) Textual structure - This refers to the arrangement and organisation of individual narrative units. Here, stylistics is interested in either large-scale elements of plot or more localized features of the story's organisation.

f) Intertextuality - The technique of allusion, intertextuality is the sixth narrative component. Narrative fiction or faction as in the case of $J B D$ does not exist in a social or historical vacuum. All narratives echo other texts and images either as 'implicit' intertextuality or as 'manifest' intertextuality.

Having explored these theoretical considerations in detail, this study next undertakes to exemplify them in the narrative structure of Omotoso's text.

\section{Narrative Structure of the Text}

Omotoso's Just Before Dawn (JBD) is a complex story about the evolution of the Nigerian state. It explores the twists and turns which have, in the course of the decades, resulted in widespread doubts about the future of the country and resulted in the 'national question'. It traces the origin, trajectory and principal architects and contributors to the country's decay. The intention of the story seems to be to prove that the prevalent disenchantment is the result of decades of inconsistency, inertia and insincerity by those at the helm of its affairs. The story, being a creative blend of fact and fiction, spans the first hundred years of Nigeria's history and includes its precolonial story.

The book opens with the military government of Murtala Mohammed (1975 - 1976) which it describes as dynamic and needed at the time to arrest the drift, douse the flame of cynicism and secure the future of the country. Accordingly, the opening statements are dramatic and capture the author's perception of the mood of that regime: 
With immediate effect! Promptly!! With dispatch!!! Without delay! In double quick time!! When Murtala Mohammed became Head of State on 29 July 1975, he was just what the country needed to sweep clean the cobwebs of the morally bankrupt Gowon regime. The future became his area of operation. What we ought to do, not what we did in the past or what we are doing now was his concern (p.1).

With the aid of the sets of exclamation marks, the author sets Mohammed off as 'an impulsive man of action' who proceeds to try to clean up corruption and inefficiency. The exclamation marks also underscore, dialectically, the abruptness and lack of depth of the regime, although the reader is unaware of this at this point. Mohammed sacks a great many in the civil service, demobilizes a large number from the armed forces and asserts Nigeria's leadership role in the African continent. But in a short time, Murtala Mohammed is felled by 'the long barrel of an aimless gun'. The circumstances of his assassination provide for the text the first major instance of the paradox of leadership ethos in Nigeria. In a bid to emphasize his Spartan and austere sensibilities by eschewing the extravagance allegedly associated with his immediate predecessor in office, the Head of State had elected to continue living in the house he had occupied as Director of Army Signal Corps and later Federal Commissioner for Communications, rather than move into Dodan Barracks, the sprawling official residence and office of the country's rulers. The implication of this was that he had to drive to and from work from his house - a policy which proved to be his undoing as he was assassinated in a failed but bloody coup d'etat on his way to work on 13 February, 1976. Beginning the story this way, Omotoso sets the literary tone for the paradox and tragedy of Nigeria as the Murtala Mohammed story illustrates Nigeria's latent greatness and reality of failure.

In this work, Omotoso explores the discourse, weaknesses, the actions, inactions, interactions and contradictions as well as the interpersonal quarrels of some of the principal beneficiaries of the post-Mohammed civilian dispensation which Mohammed's successor, Olusegun Obasanjo, had installed in 1979. In doing this, he shows how the seeds of the eventual collapse of the system are sown. He also highlights the relationship of identity which exists between those events and the events of contemporary as well as colonial times. Then the narrative examines the various controversies including the $12 \frac{2}{3}$ imbroglio of the 1979 presidential elections (a reference to the controversy surrounding the interpretation of what constituted the electoral requirement of two thirds of Nigeria's then nineteen state structure which ought to be thirteen rather than $12^{2} / 3$ ) and their aftermath. It delves into Nigeria's colonial history, the struggle for independence, personality cults and clashes, the 1966 coup d'etat, the civil war and its aftermath, the abandoned property question and finally ends with the announcement of the 1983 coup d'etat.

\subsection{Narrative Plot}

The narrative structure of the text is exceedingly complex. Although this complexity is in sharp contrast with the placid tenor of the prose, it is deliberately deployed as a response to the complexity of the subject matter: the boisterous character of the socio-political realities of Nigeria. In doing this, Omotoso dissolves the internal integrity of the text resulting invariably in the breakdown of linearity in which particular incidents are delivered denotatively as well as associatively through a variety of human images and symbols. As we have pointed out, the narrative begins with the accession of Murtala Mohammed to the country's leadership in 1976 with its brief match flare description of his dynamism and optimism. It ends with the coup d'etat of Muhammadu Buhari in 1983 - a mere seven years after.

Thus, the text begins with hope but ends with despair. It begins with a coup d'etat and ends with a coup d'etat. A Mohammed begins the story and a Mohammed (Muhammadu) ends it. Nigeria is consequently portrayed as a country going round in circles like a beheaded fowl. Between the hope at the beginning and the despair at the end of the story, a period of seven years, lie the two major subdivisions of the plot; the present consists of long stretches of military usurpation and brief civilian democratic interregnum while the past is marked by the rickety foundation laid by the British colonial powers.

As a book of faction, $J B D$ attempts to excavate the past in preparation for the future. It illustrates the fact that the past is almost a tangible part of the present and that there can be no future until the past, no matter how ugly and bloody, has been confronted squarely and placed securely in a suitable niche. According to Ofeimum in Ogunbiyi (1988), with Omotoso:

we are no longer conversing with the patriarchal teacher... the philosopher-king..., we are face to face with a fellow traveller on the streets of life, a fellow traveller who plays the tortoise and demands unsettling answers to old questions.... Omotoso is an unrepentant experimentalist who will not take the easy road to acceptability.... Omotoso's output installs itself at the interstice between the old and the new, giving 
the author a place at the bridge head of the rising echelon of younger writers whose strength has been in the urgency with which old questions are asked and fresh answers are being teased or cajoled out of the bowels of time. The questions and the answers which are implicated in Omotoso's [works] emerge largely from the author's shifting of the literary camera to the wretched of the earth (p.185).

Thus, the textual structure of the book is dominated by a back and forth movement between the present and the past and between the present and the future. The questions of the present find answers in the past whereas those of the future are located in the present. This is why at the installation of the new civilian dispensation of Shehu Shagari in 1979, three years after Murtala Mohammed's assassination, the outgoing Head of State, Olusegun Obasanjo, responding to the question about what he is handing over to the new President, declares:

I am handing over Nigeria in its totality - its past, present and future, its assets and liabilities... its hopes and aspirations, its fears and anxieties, its complexities and distinct characteristics as an African society (p.49).

This declaration early in the story serves as a narrative cue for the first of the many instances of flashbacks and time shifts in which the narrator takes the implied and real narratees by the hand 62 years back to highlight the sources of those 'fears', 'anxieties' and 'complexities'.

\section{Narrative Discourse}

The textual medium of Omotoso's $J B D$, as the study has already observed, is faction in which real life events are fictionalized in a way that blends with the country's sociolinguistic code which consists of a composite of colonialism, corruption and ethnicity. The non linear symbolism of the code, as observed, is dominated by the recurrent flashbacks and time shift devices or what Leech and Short (2007) describe as 'shifts in discourse architecture' (p.300).

\subsection{Flashback}

The series of flashbacks to the colonial era serves to shed light on current happenings in the country. For instance, when we read about the petty geopolitical bickering among Lord Lugard, Walter Crocker (D.O., Okene), Commander Carrow and Sir Donald Cameron (pp.66-67), we are better able to comprehend the political acrimony between Chief Fashoranti and Mr. Fagbamigbe, which results later in bloodletting (pp.39/335). Similarly, for the reader who seeks explanation for the incident (in the present) in which Major General Olufemi Olutoye is reported to have been retired prematurely from the army for seeking audience with, and advising, Obasanjo against pandering to what he (Olutoye) considers parochial Northern interests (pp.32-33), its parallel (in the past), in the incident between Walter Crocker and Peter (p.68) is probably where to turn.

Again, in order to understand the Bakolori massacre of peasants by the Shagari administration (in the present) (p.325), we must read (in the past) about the shooting of women demonstrating against the planned taxation (p.66). Even the rivalry between Obafemi Awolowo and Nnamdi Azikiwe (p.171) (in the present) is paralleled (in the past) by the rivalry between Commander Carrow and Donald Cameron (p.71). There is also a sense in which the rancorous debates at the 1978 Constituent Assembly (pp.33-34) can be said to resemble the acrimonious Constitutional talks at the Lancaster House Conference in London in 1947 (p.186). All these excursions into the past and projections/previsions of the future are done in order to present the present in proper contexts and exteriorise and detemporalise these realities.

In chapter eight and nine, the independence that was achieved on a precarious tripod of tribalism begins to groan under the weight of the contradictions and distress. The army, which itself was susceptible to the same contradictions, steps in to disperse the politicians. But because it (the army) consisted largely of colonial parallels, the task of cleaning up rather creates more pandemonium and civil war. Consequently, (neo)colonial interests which had been temporarily sidelined by political independence re-assert themselves in terms of the supply of arms, mercenaries and the search for peace.

This portion of the narrative is particularly significant for the light it sheds on the past life of characters like Murtala Mohammed, whom the narrator frequently addresses as 'the man of the future'. Although Mohammed's present is seen in largely positive and dynamic senses, his past, albeit not quite so edifying, intensifies his dramatic Saul-to-St.

Paul conversion on the road to Damascus as well as his eventual tragedy. Here, he is seen, together with a number of Northern army officers, embarking on the counter coup d'etat of 29 July, 1966. Asked by an exasperated Brigadier Ogundipe what the Northern army officers wanted, the man of the future replies: 
We don't want any more Nigeria, that's all. The troops from the North wish to be allowed to go back home. They have already sent their families home. Let's arrange the exchange of populations. That's all (p. 258).

Indeed, throughout the informal talks amongst army officers and permanent secretaries after the bloody counter coup, Murtala Mohammed is barely able to contain himself in his righteous indignation at what he perceives as Yakubu Gowon's (the Head of State at the time) conciliatory disposition towards the rest of the country. When Emeka Ojukwu calls Gowon on the phone, Mohammed insists on knowing every word he says before Gowon replies because according to Mohammed:

Gowon could be kind; he was not the kind of ruthless person who should deal with these people;... The only way to ensure that he did not make any commitment which they could not accept was to monitor every word that he had to say (p. 264).

Later, when Gowon continues to try to be reasonable and initiate a dialogue with Ojukwu, Mohammed, the man of the future, objects with these words: 'But let me tell you this: there is no way we are going to avoid a civil war and the earlier we fight it and win it the better for everybody' (p. 273).

In all these instances, Omotoso silently manipulates discourse to reveal character as well as the sequence of historical facts, re-ordering them to create a coherent picture of the cause, dialectics and course of the nation's decay and crises. The importance of the flashback here is, as suggested earlier, to recall the conversion of St. Paul so that when 'the man of the future' is later put to death in the putsch of 13 February, 1976, his 'martyrdom' again recalls St Paul's 'dying for the sake of the kingdom'.

The roles of other important dramatis personae of this period of the country's history some of whom are still alive today are likewise situated at the threshold of their past as well as the present and the future of the country. Links between the past and present of characters like Dimka, Ojukwu, Gowon, Obasanjo, Awolowo, Azikwe and Shagari are systematically created for the narratee in 'intervening stand stills of the period of creation'.

\subsection{Time Shift}

The sophisticated complexity of the narrative compels the narratee to be attentive. The various instances of time shift jolt him from complacency which is induced by reading about a familiar historical account into compulsive attentiveness. The effects of these devices are discussed by Ofeimum in Ogunbiyi (1988, p.193) when he refers to Omotoso's stylistic techniques in the book's narrative and speaks of this tendency:

to problematise through switches of point of view, flashbacks and movements between fantasy and the real. It could frustrate the careless reader. All the same, the switches from one narrator to the other and the shuttles between flashbacks and anticipations which may at first appear like a hindrance become in the end an aid to empathy... the switches from one point of view to another is therefore in the long run a device that inclines the reader to look into a collective, rather than just an individualistic vision.

We read about a 1920 incident involving a farmer named Abdul. Abdul had come to complain to Dr Walter Miller of the CMS in Zaria that the Emir had appropriated his farm. We are told that the corrupt Emir was propped up by an equally corrupt British Resident who condoned the Emir's malfeasance. When Dr Miller writes the Resident, he replies that the issue is being looked into by the Emir! Miller writes to Governor Hugh Clifford in Lagos, who, after discreet investigations, imposes sanctions on the Emir, but Miller is warned to mind his business (p.108).

As the reader settles for a chronological follow-up to the story, the narrative shifts abruptly to 4th June, 1888, to an incident involving Madam Adeola at Ebute Ero market in Lagos. She has been hurt in a violent altercation and is rushed to the colonial hospital in Lagos. But the hospital's assistant's surgeon, Dr Cecil Digby, has no time for black patients and so Madam Adeola does not receive treatment until 20th June, sixteen days later, when she is secretly dumped in a nearby bush. Reverend James Johnson hears about it and gets her readmitted into the hospital where she dies a few days later. The furore generated by her death results in the institution of an enquiry into the incident. The coroner returns a verdict of death by natural causes, and Dr. Digby and his accomplices are acquitted (pp.108-109).

As the reader begins to wonder what connection exists between the two anecdote-like episodes above, the narrative in the same breath shifts further to 19th September, 1873. The occasion is the founding of the Lagos based society for the Promotion of Religion and Education during which its secretary indicts some of its white missionaries for selfishness, inertia and apathy towards public interests and public good. The narrator observes that the indictment 
'could equally describe other white professionals'(p.109). What these somewhat disparate incidents have in common becomes apparent only with further reading as we discover that this is the narrator's method of demonstrating a pattern to barefaced colonial oppression, treachery and injustice even as they (colonialists) claimed lofty ideals and humane motives. In both instances, it is the citizen - the face from the crowd - who is victimized. As the narratee ponders on the activities of the Emir, a corrupt protégé of colonialism, who connives to deny Abdul his rights, he is provided 'fresh answers' to 'old questions' from 'a fellow traveller on the streets of life'. For, as Ofeimum (1988, p.187) suggests, these questions and answers:

emerge largely from the author's shifting of the literary camera to the wretched of the earth, the innocent, the helpless, those who suffer the pangs of wants, suffering and deprivation; those who do not enjoy even the wretched opulence of our neo-colonial age.

Another instance of the narrative's complex time-shift technique occurs in the narration of the build-up to the January 1966 Nigerian coup d'etat. The narrator informs the reader that following the unrest in Nigeria's Western region, the army is called in to restore order. But the military operation cannot begin because the Commonwealth conference is holding in Lagos at the time and ends on the 13th of January, 1966. On that day, the British Prime Minister, Harold Wilson, privately hints his Nigerian counterpart, Tafawa Balewa, about intelligence reports concerning an impending coup, and offers to assist if Balewa needs help - offers which Balewa brusquely rejects. In the narrator's uniquely poignant style designed to presage as well as intensify Balewa's tragedy, he, the narrator, does not forget to add that Wilson offered Balewa 'some rooms in the High Commission, so that you don't have to go back to your residence straight away' (p.234).

Conforming to historical accounts of Balewa's demeanour of fierce patriotism and naïve grandeur, the narrative shifts abruptly from this point to a period antecedent to the commencement of the conference on 11th January, 1966. Balewa has gone to Kaduna (Northern regional headquarters) from Lagos to confer with Ahmadu Bello (Premier of Northern region and leader of his party) about his anxieties concerning the situation in the West in particular and the country in general, and the need to take decisive action. The Sardauna (Bello), on his way to perform the lesser Hajj, Umra, tells Balewa not to worry. From here the story returns abruptly to 13th January, 1966, the end of the conference and the return of Ahmadu Bello from the Hajj. On his arrival, he is telephoned by the Prime Minister and the following dialogue ensues:

'When I arrived today, someone at the airport gave me an anonymous letter,' replied the Sardauna, 'saying something about a coup d'etat. I wouldn't bother myself with such a thing.'

'The federal parliament meets on Monday, the 17th, to do something about the West.'

'What exactly?' the Sardauna asked sharply.

'A state of emergency, to begin with,' said the Prime Minister.

'Akintola is our political ally,' responded the Sardauna, 'you must give him more time.'

'But he is not doing anything with what he has been given!'

'How do you know?' the Sardauna snapped back. The Prime Minister decided to change the topic. 'How was your Umra?' (pp. 235-236).

Now, who is the leader of the country here - the Prime Minister, Tafawa Balewa, or the Sardauna, Ahmadu Bello, the Premier of just one part of the country, the North? This piece of discourse is significant not just for what it reveals about the character of each man and their interpersonal relationship but also the tragic contradictions of Nigeria's leadership architecture.

Between the first and second accounts of the 13th January, 1966 events, there is a piece of interior monologue which seems to connect them both. In it, Balewa reveals to the reader his thoughts on the difficulties he is having with the Sardauna, which have earned him the demeaning epithet of errand boy to the Sardauna. Balewa sees this as unfair because he has always struck an appropriate balance between his deference to the Sardauna and the North on the one hand, and a measure of independence in decision making on the other. He recalls the instance of his choice of Aguiyi Ironsi as Army GOC to succeed Welby Everald rather than Babafemi Ogundipe (Welby Everald's choice), Samuel 
Ademulegun (Sardauna's choice) or Zakary Maimalari (North's choice). Some of these time shifts give the episodes they refer to the qualities of potentially great short stories.

Shortly after this, Samuel Akintola, Premier of the West, visits the Sardauna on the 14th of January, 1966, and hints at an impending coup. As the Sardauna again brushes this aside, Akintola importunes him:

'... I am telling you that they are going to kill us today!'

'My defence is in the hands of Allah,' intoned the Sardauna like a Sufi. Akintola

shook his head and went into the plane to return to Ibadan and his death (p.236).

The narrative here is remarkable for the way in which an even, almost sleepy tenor of the narration results in such a tragically prophetic incident. The abrupt connection between the present and the future is underscored by the device of zeugma which results in the neutral prevision of Akintola's death.

With Akintola's departure for Ibadan, the Sardauna returns from the airport and is informed of a young army officer in civilian clothes going around his residence. It is when he accosts the young man, who claims to be checking the security systems in the house, that an earlier incident ten years before involving someone who resembled this same young man flashes through his mind. The narrative abruptly goes back to the occasion of the visit of the Queen of England with her husband during which security had been tight. He, Ahmadu Bello, had not brought his pass because he expected anyone in Kaduna to recognize him. But his car had been stopped and he had been asked to produce a pass. He had got out of his car and announced who he was and asked the young man who he was, to which he replied: 'I am an Ibo sir,' and turned back the Sardauna who went away muttering to himself: 'An Ibo, an Ibo.' The references to 'Ibo' here are significant because the coup d'etat which occurs on the 15th of January, the very next day (future), is later widely seen as an Ibo coup resulting in reprisal bloodletting and a countercoup against the Ibos.

The next time-shift episode takes the reader back to December 1964 to the preparations for the federal elections of that year. Here, we see Emeka Ojukwu, an army officer, and Nnamdi Azikiwe, the President, discussing plans for a UPGA (United Progressive Grand Alliance) boycott of the elections and Azikiwe's take-over of power (p.239). Part of this story has already been told (pp.227-230) before the episodes of the Commonwealth conference and Akintola's visit to the Sardauna. In the earlier part of the narrative, Azikiwe has already attempted the take-over on the 1st of January, 1965 after the elections have been boycotted wholly in the East and partially in the West. The Prime Minister has sought and secured the advice and support of service chiefs, Welby Everald (army), Akinwale Wey (navy) and Louis Edet (police) in anticipation of a possible conflict with President Azikiwe.

But now in the present, the reader is treated to a detailed narrative on Azikiwe's preparations for the take-over including his unsuccessful attempt to secure the support of the above named service chiefs. Chronologically, Azikiwe's effort is supposed to occur before, rather than after, that of the Prime Minister's. Thus, the breakdown of linearity of this factual, familiar story turns it into an imaginative work of art, fictionalizing it. This is a technique the author deploys again and again. Again, before sending for the service chiefs, we are told, Azikiwe seeks advice from the Chief Justice of the Supreme Court, the Attorney General of the country and the Chief Judge of the Eastern region about his intention to take over. But they tell him that it would be unconstitutional (p.228). It is not until eleven pages later that the reader is treated to the full details of their discussion (pp.239-240).

Yet another example of the narrative time-shift technique occurs when, as we are told, Aguiyi-Ironsi has assumed leadership of Nigeria following the failure of the January, 1966 putsch and suspended the constitution. The narrative yet again breaks off abruptly and begins to explore some of the aims of the putsch and the process of execution. Here, the coup makers take over the narrative and inform the narratee that the aim of the coup was that: '...power must be wrested from the hands of the NPC [Northern People Congress] if the country was ever to make any headway in the modern world'(p.248). The failure of the coup as a result of the failure of Major Obienu, who was charged with the responsibility of moving arms over to Lagos from the Abeokuta armoury, to appear with the arms on the day of the coup is described with pathos and irony. Maimalari, who was instrumental to the establishment of that armoury at the prompting of Emmanuel Ifeajuna and Emmanuel Nwobosi for the very purpose of the coup itself, later becomes a principal victim of the coup.

The time shift here achieves two aims. First, it lets us see how Ironsi comes to assume leadership, and, second, it attempts to juxtapose by innuendo the ethnic identity of the names of the coup makers (Nzeogu, Ifeajuna, Obienu, Nwobosi) and the beneficiaries (Ironsi, Ojukwu) (p.249). All over the text, there are episodes arranged non-chronologically to elucidate specific contemporary questions. Thus, in order to exemplify the imperial ambition and peremptory disposition of the contemporary Ojukwu as he discusses with Azikiwe plans to discredit the impending federal elections of 1964, the narrator undertakes to place him (Ojukwu) in sharper focus by abruptly 
dramatising for the narratee Ojukwu's days at Oxford University. The occasion is an evening of a small gathering of soon-to-graduate students on a Friday night during which each person speaks of what he or she would like to do after graduation. When it is Ojukwu's turn, with supreme cynicism at his classmates' real motives for asking such a question, he replies: 'I am going to be the King of Nigeria!' With this past detail in Ojukwu's life, Omotoso sheds light on his present uncompromisingly imperious stance in the aftermath of the counter coup of 29th July, 1966. As we have observed, the time shifts here episodicise and problematise the story of Nigeria. The breakdown of linearity reinforces the notion that Nigeria's true story is stranger than fiction.

\section{Chapter Titles}

As part of the text's narrative strategy, there is a great deal that the chapter titles contribute to the narrative style of the text. The chapter titles are all semantically cryptic but surely symbolic of the author's private and poetic interpretation of the events in each chapter. There are thirteen chapters in the text. The first chapter entitled 'The Long Barrel of an Aimless Gun' introduces to the narratee Murtala Mohammed's brief reign including how and why he is assassinated in the Dimka abortive coup in February, 1976. The coup is long in rhetoric but aimless in purpose and planning; it is not designed, the narrative tells us, to achieve any specific noble aim. Thus, Dimka's gun is long barrelled because it consumes (reaches) several victims, but it is aimless (not specifically targeted). Dialectically also, the Murtala Mohammed's regime is long in its claim to dynamism but short (aimless) in clear thoughtfulness and life span.

In the second chapter, Obasanjo inherits the mantle of leadership on his boss' assassination. But he also inherits the hopes, fears and problems of the nation, which he in turn prepares to hand over to the incoming politicians. The chapter is appropriately entitled 'Handing Over'. The next chapter, 'The Imitation Raj Disposes', at first poses an interesting challenge to interpretation. It forces the reader into a deeper reflection about the semantic implication of the lexical items 'Imitation Raj' as well as what the expression is supposed to be disposing. Further reading reveals that the clue to its meaning resides in the item 'raj'. As a lexical item of the common noun category, it is derived from Hindi language meaning 'government'; 'rule', but as a proper noun, 'the Raj' refers to the British government in India prior to independence in 1947.

The story of Indian struggle for independence reveals the characteristic divide and rule strategy of British colonialism. In order to neutralize the influence of the charismatic M.K. Gandhi, who led the independence movement through non-violent protests, the British exploited the sectarian sentiments and fears of Muslim Indians (now Pakistan) led by Mohammed Ali Jinnah, who were apprehensive of being swallowed up in a haze of oppression by the majority Hindus in an independent India. The result was crisis and bloodshed in which over a thousand people lost their lives, and finally partition (Browne, 2007, pp.136-143).

Close reading of the events in 'The Imitation Raj Disposes', therefore, reveals not just Omotoso's sense of history but also interesting parallels between the British Raj in pre-independence India and Nigeria. We read of the various antics of the British colonial officers exploiting the fears and apprehension of Northern Nigerians in the worst form of divide and rule in order to blunt the independence struggle led by Nnamdi Azikiwe and Obafemi Awolowo. Coming as this chapter does directly after 'Handing Over', which, as we have observed, raises hopes, the actions of the British colonial authorities ('Imitation Raj' for replicating British treachery in India) could be said to have 'disposed' those hopes.

The next chapter, 'Their Field of Play' appropriately examines the various geographical settings of these acts of disposing in Nigeria; that is, the various parts of Nigeria in which sundry political theories which were developed elsewhere and often contradictory are tested. These settings (field of play) as revealed in the narrative include Kontagora, Keffi, Oyo, Akassa, Nikki, Obowo, Lagos, Dumbulwa, Zaria, Rabah and Ebute Ero. Next comes chapter five in which the life and careers of each of Azikiwe, Awolowo and Bello are faithfully portrayed including the 'so much promise but little fulfilment' which their titanic personalities held for Nigeria. This chapter is dialectically entitled 'The Big Three', and the theme of the chapter is summed up in the subtitle: '...but it was an age of promise rather than of fulfilment'.

Chapter six is entitled 'Trial of the Zikists' (Note the absence of the definite article 'the' before the word 'trial'), and it examines the circus show which became of colonial administration of justice as exemplified in the trial of the young men who claimed to be followers of Nnamdi Azikiwe such as Chukwuemeka Ugokwu, Abiodun Aloba, Kola Balogun and Ikenna Nzimiro. In the course of the trial, which is a study in no trial at all - for, that is what the absence of the definite article connotes - Ugokwu deftly turns his accusers to the accused, and the 'trial' metamorphoses into a trial of British colonial policies in Nigeria. 
'The Frantic Fifties', chapter seven, is concerned with the development of pre-independence party politics, tribalism, constitutional talks and the beginnings of regional and ethnic suspicion and tension. At this point, the speeches and actions of the politicians are full of fear and anxiety. They are frantic. Chapter eight discusses the skewed nature of the federation bequeathed by the independence constitution, which gave overwhelming advantages to the North, and the spate of crises resulting from it. It also examines the attempts to wrest federal power from, and control, the North, Azikiwe's attempted take-over of power and hints about the impending 15th January coup d'etat. It is entitled 'Who Gets the North Rules'.

In chapter nine, 'Unity in Diversity', the coup d'etat has taken place, Ironsi is Head of State, and there are tensions mostly ethnic. The military authorities embark on discussions and consultations, which are almost belated, concerning the threatened unity of the country. The various units in the country at this point are united only in their desire to quit the federation. They who initially desired to be one despite their diverse natures are now united in wanting a break-up (diversity). The chapter is a study in paradox and dialectics. This is followed in chapter ten by an examination of the hard-line positions adopted by the principal participants in the talks to avert the looming crisis and war. The chapter explores the Aburi talks and the outbreak of the war. It is entitled 'The Nation in a State of War'.

Chapter eleven exploits the homophonic similarity (pun) between the war time federalist slogan, 'To keep Nigeria one is a task that must be done', which expresses in a pithy manner the ostensible aim of the war, and what the author, from post war hindsight, considers the real aim of the prosecution of the war: 'To keep Nigeria Worn'. The word play is on 'one' in the real slogan and 'worn' in the chapter title because the chapter consists in the various acts of government officials and society which wore, and continue to wear, away the moral fibre of the nation. As the chapter observes: 'In retrospect it is difficult to say which had the more devastating effect on the unity of Nigeria: the civil war with all its injustices and inhumanities or the post civil war oil boom with all its corruption and soul destroying immoralities' (p.299).

The last two chapters, twelve and thirteen, are entitled 'Unlimited Liability' and 'Strange Bedfellows' respectively. The phrase, 'unlimited liability' is particularly apt as it portrays Nigeria at this point as a company whose directors have mortgaged all her assets including paid or unpaid par value of shares turning her into a huge liability. Shehu Shagari presides over this monumental brigandage and turns his administration into an unlimited national liability. 'Strange Bedfellows' explores the curious and unworkable political alliances between NPN (National Party of Nigeria) and NPP (Nigerian People's Party), and later among UPN (Unity Party of Nigeria), NPP and GNPP (Great Nigerian People's Party) especially as these alliances mock the failed and tragic alliances of the past. It deals with the strange bedfellows who cohabit these parties and who precipitate the 1983 election malpractice and the violence which accompanies it culminating in another coup d'etat. Buhari, who becomes the Head of State, was himself a high ranking military cum political appointee of the government he has toppled. These chapter titles foreground in a symbolic, poetic style the author's impressions about the various strands of the discourse on Nigeria some of which impressions are not explicitly stated. The titles therefore underscore the multi-layered interpretation of the events in the text.

\section{Graphological Device}

Yet another aspect of the narrative style of the text occurs at the graphological level. Here again, Omotoso's unusual graphological style manifests itself in the dialectical symbolism of his preference for lower case letters rather than capitals and vice versa to designate the proper titles or common names of the characters. Consider the following examples: inspector-general (p.2); obi (p.87); emir (pp.78/107/131); sardauna (p.133), and Gods (p.309). At first, the reader is slightly perplexed at this phenomenon. All the lexical items save for the last one usually and traditionally have proper reference, being nouns that are normally one of their kinds in the context. And so why does the author begin specific proper titles with lower case letters, and the common noun 'gods' with an upper case letter? The answer lies in the narrator's perception of the roles which the characters so designated perform in relation to the socio-political problems of the country.

Traditional or conventional literary appraisal will most likely perceive only a laudatory attitude in the author's assessment of the characters. Stylistic criticism enables the reader to read between, not just the lines but also, the letters and go beyond the 'urbane, cultivated and relaxed' personae (p.2) and appreciate the paradox of the distress, 'grave economic predicament and uncertainty' (p.344) which they help to create. In other words, the presentation of these characters' designations with small letters represents a dialectical assessment of their roles. On the other hand, the capital ' $g$ ' which begins the small letter 'god' attests to the trouble-shooting role of the Sebastian Okoro family 'gods'. Here, the 'Gods' are called upon to provide succour and replenish their stock, which has been hugely 
depleted by the just ended civil war, which the small letter characters helped to create. The paradox in the author's perception of the roles of these characters is reflected in this reverse use of graphology. By this device, the characters are to be seen as ironic archetypes of the main actors in any dialectics of struggle and social change. For they represent instances of inertia, overzealousness and solicitude rather than agents of law, order, good governance and minor deity as the case may be the world over.

\section{Conclusion}

This study has employed a narrative stylistic theory to reveal the ways in which Omotoso exploits narrative discourse elements in order to demonstrate a correlation between past and present action as well as the manipulation of narrative sequence for didactic purposes in Just Before Dawn. The principal discourse strategies here are flashbacks, timeshift, chapter titles and graphology. With these devices, the narrator frequently takes the reader (narratee) by the hand back and forth a hundred years into Nigeria's socio-political history, delivering denotatively and associatively the historical parallels between contemporary events, their sources, courses and future.

The textual medium of the work is a creative blend of fact and fiction often referred to as faction in which familiar real life events and characters commingle with their symbolic counterparts. The socio-linguistic code of the narrative is a composite one in which images of betrayal, treachery, corruption, lust for power and brief life affirming leadership values are expressed in plain and lucid English. The unique stylistic aspects of narrative characterization are exemplified through the manipulation and juggling of graphology in terms of the 'doing', 'thinking' and 'saying' of the characters. The textual structure of the work consists of large-scale elements of plot whose physical linear connectivity is disrupted frequently by flashbacks, prevision, time shift and the deeper social symbolism of its chapter titles. It is this deeper symbolism which best illustrates the book's intertextuality in the sense that the forward and backward movements of the narrative reflect the country's chequered history delivered creatively and imaginatively.

\section{References}

Browne, H. (2007). World history (2) 1900 - 2005. London: Cambridge University Press.

Chapman, R. (1973). Linguistics and literature. London: Edward Arnold.

Coupland, N. (2007). Style: Language variation and identity. Cambridge: Cambridge University Press. http://dx.doi.org/10.1017/CBO9780511755064

Leech, G. \& Short, M. (2007). Style in fiction. Harlow: Pearson Education Limited.

Leech, G. (2008). Language in literature. Harlow: Pearson Education Limited.

Matthews, P. H. (2007). The concise Oxford dictionary of linguistics. Oxford: Oxford University Press.

Mikov, G. (2003). Linguistic stylistics. Nitra: Filozofick Faculta Univerzita Kontantna Filozofa.

Mills, S. (1995). Feminist stylistics. London and New York: Routledge.

Ofeimum, O. (1988). Kole Omotoso, Ogunbiyi, Y. Ed. Perspectives on Nigerian literature: 1700 to the present Vol 2. Lagos: Guardian Books Nigeria Ltd. 185 -194.

Olateju, M. (2004). Discourse analysis. Ife: Obafemi Awolowo University Press.

Omotoso, K. (1988). Just before dawn. Ibadan: Spectrum Books.

Simpson, P. (2004). Stylistics. London and New York: Routledge

Ufot, B. (2006). An introduction to practical stylistics. Lagos: Solar Flares Communications.

Wales, K. (2011). A dictionary of stylistics. Harlow: Pearson Longman.

Widdowson, H. G. (1975). Stylistics and the teaching of literature London: Longman. 